\title{
Persepsi Masyarakat Nagari Batu Bajanjang Terhadap Rencana Pembangunan Pembangkit Listrik Tenaga Panas Bumi Gunung Talang
}

\author{
Nia Cahya Ningsih, Nurman S \\ Jurusan Ilmu Sosial Politik \\ FIS Universitas Negeri Padang \\ E-mail: niacahyaningsih2018@gmail.com
}

\begin{abstract}
ABSTRAK
Dalam rangka mewujudkan tercapainya tujuan pembangunan nasional pemerintah Indonesia terus mengusahakan pembangunan dengan memanfaatkan sumber daya alam yang ada salah satunya panas bumi. Pembangunan merupakan proses multidimensi dalam perubahan-perubahan seperti struktur sosial, sikap rakyat dan lembaga-lembaga nasional. Oleh karena itu dalam penelitian ini penulis akan meneliti tentang persepsi masyarakat terhadap rencana pembangunan Pembangkit Listrik Tenaga Panas Bumi (PLTP) Gunung Talang di Nagari Batu Bajanjang, Kecamatan Lembang Jaya, Kabupaten Solok. Alasan penulis mengambil topik ini karena di nagari tersebut akan dibangun PLTP. Jenis penelitian ini ialah kualitatif dengan metode deskriptif. Purposive sampling digunakan sebagai teknik dalam penentuan informan penelitian. Data dikumpulkan melalui teknik observasi, wawancara dan dokumentasi, sedangkan teknik analisis data pada penelitian ini digunakan teknik Miles dan Hurben (1984) dengan tahapan reduksi data, penyajian data, dan verifikasi data. Hasil penelitian menunjukan bahwa.rencana pembangunan Pembangkit Listrik Tenaga Panas Bumi (PLTP) Gunung Talang yang akan dilakukan oleh PT Hitay Daya Energi menimbulkan berbagai pandangan atau persepsi dari masyarakat Nagari Batu Bajanjang sehingga terdapat dua kelompok persepsi masyarakat yaitu menerima (setuju) dan menolak (tidak setuju), persepsi masyarakat ini dipengaruhi oleh pemahaman masyarakat terhadap PLTP dan dampak yang ditimbulkan (dampak sosial, ekonomi dan lingkungan). Selain itu untuk meningkatkan pemahan masyarakat pemerintah dan PT melakukan sosialisasi kepada masyarakat namun tidak berjalan optimal.
\end{abstract}

Kata Kunci: pembangunan Pembangkit Listrik Tenaga Panas Bumi (PLTP), masyarakat, pemerintah, sosialisasi

\section{ABSTRACT}

In order to realize the achievement of national development goals the Indonesian government continues to strive for development by utilizing natural resources, including geothermal. Development is a multidimensional process of change such as social structure, people's attitudes and national institutions. Therefore in this study the author will examine the community's perception of the planned development of the Mount Talang Geothermal Power Plant (PLTP) in Nagari Batu Bajanjang, Lembang Jaya District, Solok Regency. The reason the author takes this topic is because in the village will be built PLTP. This type of research is 
qualitative with descriptive methods. Purposive sampling is used as a technique in determining research informants. Data were collected through observation, interview and documentation techniques, while the data analysis technique in this study used Miles and Hurben (1984) techniques with the stages of data reduction, data presentation, and data verification. The results showed that the development plan of the Mount Talang Geothermal Power Plant (PLTP) of Mount Talang which will be carried out by PT Hitay Daya Energy raises various views or perceptions of the people of Nagari Batu Bajanjang so that there are two groups of community perceptions, namely accepting (agreeing) and rejecting (not agree), this community perception is influenced by the community's understanding of the PLTP and its impacts (social, economic and environmental impacts). In addition to increasing community dividing, the government and $P T$ carried out socialization to the community but it did not run optimally.

Keywords: development of Geothermal Power Plant (PLTP), community, government, socialization

cc) (i) (2) This work is licensed under the Creative Commons Attribution-ShareAlike 4.0 International License. @2020 by author.

\section{PENDAHULUAN}

Pembangunan di Indonesia terus berjalan dan semakin meningkat sejalan dengan pertumbuhan ekonomi dan pertambahan peduduk. Dimana pembangunan merupakan suatu kegiatan mengadakan sebuah objek bangunan pada suatu daerah yang mempunyai suatu fungsi untuk kedepannya. Pembangunan menjelaskan proses dan usaha untuk meningkatkan kehidupan ekonomi, politik, sosial, budaya, infrastruktur masyarakat dan sebagainya. (Alpriandi.dkk, 2019:20). Selain itu, pembangunan dilaksanakan untuk mewujudkan tujuan nasioanal sebagaimana tercantum dalam pembukaaan UUD 1945, yaitu melindungi segenap bangsa dan seluruh tumpah darah Indonesia, memajukan kesejahteraan umum, mencerdaskan kehidupan bangsa, serta ikut melaksanakan ketertiban dunia yang berdasarkan kemerdekaan, perdamaian abadi, dan keadilan sosial. (Utari. dkk, 2019:69).

Pelaksanaan pembangunan dalam aspek kehidupan masyarakat berbangsa dan bernegara dilakukan oleh pemerintah bersama-sama dengan komponen yang ada dalam masyarakat. Selain masyarakat dan pemerintah pembangunan juga berkaitan erat dengan lingkungan. Pembangunan dan lingkungan merupakan dua komponen yang tidak dapat dipisahkan dan saling mempengaruhi. Pelaksanaan pembangunan membutuhkan faktor lingkungan, baik lingkungan fisik (alam) maupun lingkungan sosial (manusia). (Supyana, 2015).

Dalam rangka mewujudkan tercapainya tujuan pembangunan nasional pemerintah Indonesia terus mengusahakan pembangunan dengan memanfaatkan sumber daya alam yang ada salah satunya panas bumi. Potensi panas bumi di Indonesia tercatat mencapai $40 \%$ cadangan panas bumi dunia. (Mangensiga, 2020:15). Sumatera Barat merupakan salah satu provinsi di Indonesia yang memiliki potensi energi panas bumi yang cukup besar. Potensi yang ada di provinsi ini dapat dikembangkan menjadi tenaga listrik yang berguna sebagai alternatif dan 
suatu inovasi dalam memenuhi kebutuhan energi dimasa mendatang. (Meilani dan Dewi, 2010). Rencana Pembangunan PLTP di kaki Gunung Talang, Kabupaten Solok telah dimulai sejak tahun 2016 oleh PT Hitay Daya Energi yang memenangkan lelang Wilayah Kerja Panas Bumi (WKP) Gunung Talang dan mendapatkan izin pembangunan panas bumi seluas 27.000 hektar di kawasan Gunung Talang dalam jangka waktu 37 tahun, (Keputusan Menteri ESDM Nomor 7257 $\mathrm{K} / 30 / \mathrm{MEM} / 2016)$. Lokasi izin berada dalam kawasan hutan lindung, dengan fokus pembangunan akan berpusat pada Nagari Batu Bajanjang, Kecamatan Lembang Jaya, Kabupaten Solok. (Hadi dan Eka, 2019: 237).

Rencana

Pembangunan

Pembangkit Listrik Tenaga Panas Bumi (PLTP) ini menimbulkan pro-kontra baik dari masyarakat, pemerintah, maupun pihak terkait. Sehingga pembangunan ini terkendala pada permasalahan sosial seperti penolakan masyarakat. Berdasarkan observasi awal penulis melalui pengamatan, penulis melihat daerah yang akan dijadikan kawasan pembangunan Pembangkit Listrik Tenaga Panas bumi ini terletak di kawasan hutan lindung yang disikitarnya dikelilingi kawasan perladangan masyarakat, dengan suasana hening, asri dan sejuk. Disekitar kawasan rencana pembangunan PLTP juga terdapat spanduk-spanduk yang berisi tulisan-tulisan aspirasi dan penolakan masyarakat terhadap PLTP. Sehingga masyarakat Nagari Batu Bajanjang menolak terhadap rencana pembangunan PLTP dan menyampaikan aspirasi mereka melalui aksi-aksi penolakan seperti demo yang telah berulang kali dilakukan.
Jadi dapat dipahanmi bahwa sebagai faktor penting dalam kegiatan pembangunan sebagai pelaksana, masyarakat memiliki andil dalam pengambilan keputusan rencana pembangunan Pembangkit Listrik Tenaga Panas Bumi (PLTP). Sikap dari masing-masing masyarakat baik dukungan maupun penolakan memiliki alasan tersendiri. Untuk menunjang pembangunan pembangkit listrik tenaga panas bumi perlu sekiranya dilihat persepsi masyarakat khususnya masyarakat Nagari Batu Bajanjang mengenai pembangunan PLTP tersebut. Persepsi yang ada pada masyarakat melandasi partisipasi masyarakat terhadap kegiatan pembangunan. Maka dari itu penulis tertarik untuk mengkaji lebih jauh sehingga permasalahan yang ada akan terjawab. Oleh karena itu peneliti memfokuskan kepada "Persepsi Masyarakat Terhadap Rencana Pembangunan Pembangkit Listrik Tenaga Panas Bumi (PLTP) di Nagari Batu Bajanjang, Kecamatan Lembang Jaya, Kabupaten Solok"

Penelitian tentang Persepsi masyarakat telah banyak dilakukan oleh peneliti-peneliti terdahulu antara lain: penelitian yang dilakukan oleh Wangke (2010) meneliti tentang "Persepsi Masyarakat terhadap Kegiatan Pengembangan Lapangan UAP dan PLTP Unit 5 dan 6 PT Pertamina Gheothermal Energy". Dapat disimpulkan bahwa persepsi masyarakat terhadap kegiatan yang dilaksanakan di Clauser LHD-26, Clauser LHD-32, dan dilokasi pengambilan air Sungai Maasem adalah positif.

Selanjutnya penelitian yang dilakukan oleh Djumaty (2015) tentang Persepsi dan Sikap Masyarakat Desa Idamdehe terhadap Rencana 
Pembangunan PLTP di Idamdehe dan Idamdehe Gamsungi". Dapat disimpulkan bahwa tanggapan sebagian besar masyarakat di Desa Idamdehe tentang pembangkit listrik tenaga panas bumi sangatlah baik dan atas dasar itulah sehingga kebanyakan dari masyarakat menyetujui akan rencana pembangunan PLTP di desa tersebut. Namun setelah masyarakat medapatkan informasi yang sepadan yaitu ada dampak di balik pembangun ini persepsi masyarakat mulai berubah dan kembali menolak terhadap rencana pembangunan ini. Kemudian penelitian yang dilakukan oleh Supyana (2016) meneliti tentang "Persepsi Masyarakat Terhadap Pembangunan PLTU di Desa Ujungnegoro, Kecamatan Kandeman, Kabupaten Batang (kajian tingkat pendidikan)". Dapat disimpulkan bahwa adanya pengaruh tingkat pendidikan terhadap persepsi masyarakat terhadap pembangunan PLTU sebesar 33,7\%. Semakin tinggi tingkat pendidikan yang ditempuh, semakin tinggi pula skor persepsi masyarakat dalam memberikan respon positif terhadap pembangunan.

Sehubungan dengan penelitianpenelitian di atas, Penelitian ini memiliki perbedaan pada subjek, objek, dan fokus penelitian dengan penelitian sebelumnya, sedangkan persamaan penelitian ini dengan penelitian terdahulu adalah sama-sama mengkaji masalah persepsi masyarakat terhadap pembangunan pembangkit listrik. Melalui artikel ini peneliti akan menggambarkan bagaimana persepsi masyarakat Nagari Batu Bajanjang terhadap rencana pembangunan Pembangkit Listrik Tenaga Panas Bumi (PLTP) Gunung Talang.

\section{Metodologi Penelitian}

Jenis penelitian yang digunakan ialah kualitatif dengan metode deskriptif. Bogdan dan Taylor (dalam Moleong, 2013:4) menjelaskan bahwa penelitian kualitatif adalah suatu prosedur penelitian yang menghasilkan data deskriptif berupa ucapan atau tulisan dan perilaku orang-orang yang diamati. Penelititian ini dilakukan di Nagari Batu Bajanjang, Kecamatan Lembang Jaya, Kabupaten Solok. Penentuan informan dalam penelitian ini yaitu menggunakan teknik purposive sampling. Informan dalam penelitian ini terdiri dari 13 orang yaitu wali Nagari Batu Bajanjang (kepala desa), kepala Jorong (RT) Bawah Gunuang, kepala Jorong (RT) Gurah, 4 orang tokoh adat (niniak mamak, bundo kanduang dan cadiak pandai), 2 orang tokoh pemuda dan 5 orang masyarakat umum. informan yang dipilih dianggap paling tahu dan memiliki pengetahuan yang cukup serta mampu menjelaskan keadaan sebenarnya tentang objek yang diteliti dan juga informan tersebut dipercaya masyarakat untuk menyampaikan pendapat dan pandangan mereka. Data dikumpulkan melalui observasi dan wawancara mendalam, serta dokumentasi. Pada penelitian ini teknik uji pengabsahan data yang digunakan adalah triangulasi. Triangulasi menurut Moleong (2009: 330) ialah teknik pemeriksaan keabsahan data yang dimanfaatkan sesuatu yang lain dari luar data yang digunakan untuk keperluan pengecekan atau sebagai pembandingan terhadap data tersebut. Analis data pada penelitian ini menggunakan teknik Miles dan Hurben (dalam sugiyono, 2017:334-343) dengan tahapan pengumpulan data reduksi data, penyajian data penarikan kesimpulan.

Hasil Penelitian Dan Pembahasan 1. Persepsi Masyarakat Terhadap 


\section{Rencana Pembangunan Pembangkit Listrik Tenaga Panas Bumi (PLTP) Gunung Talang}

Berdasarkan kenyataan yang penulis temukan di lapangan persepsi masyarakat Nagari Batu Bajanjang terhadap rencana pembanguan pembangkit listrik tenaga panas bumi (PLTP) berbeda-beda. Perbedaan persepsi ini menimbulkan sikap masyarakat yang setuju dan tidak setuju terhadap rencana pembangunan pembangkit listrik tenaga panas bumi (PLTP) Gunung Talang. Hal ini sesuai dengan penjelasan Listyana dan Yudi (2015:121) bahwa persepsi masyarakat akan menghasilkan suatu penilaian terhadap sikap prilaku dan tindakan seseorang didalam kehidupan bermasyarakat.

Menurut Sarlito W.Sarwono dalam Listyana dan Yudi (2015:122) ada lima faktor-faktor yang mempengaruhi persepsi. Faktor-faktor ini sesuai dengan kenyataan yang penulis temukan dilapangan seperti; pertama perhatian, perbedaan fokus perhatian antara satu dengan yang lain akan menyebabkan perbedaan persepsi. Hal ini lah yang terjadi pada masyarakat Nagari Batu Bajanjang perbedaan perhatian terhadap dampak yang diberikan oleh pembangunan pembangkit listrik tenaga panas bumi (PLTP) menimbulkan masyarakat menerima (setuju) dan menolak (tidak setuju) pembangunan dilakukan.

Kedua kesiapan mental, ketidak siapan mental, sebahagian besar masyarakat Nagari Batu Bajanjang yang mengkhawatirkan akan kehilangan mata pencarian utama mereka sebagai petani, sedangkan sebagian kecil masyarakat menerima pembangunan Pembangkit Listrik Tenaga Panas Bumi (PLTP)
Gunung Talang dikarenakan mereka siap untuk menerima suatu perubahan yang mana mereka berpandangan kehadiran PLTP Gunung Talang ini akan menambah kesejahteraan mereka seperti akan membuka peluang kerja baru dan menaruh harapan untuk menambah pemasukan asli daerah mereka sehingga Nagari Batu Bajanjang akan menuju pada suatu kemajuan.

Ketiga kebutuhan, persepsi masyarakat Nagari Batu Bajanjang juga dipengaruhi oleh kebutuhan, seperti masyarakat yang menolak (tidak setuju) adalah mayoritas petani yang mana mereka membutuhkan keasrian alam, kesuburan tanah serta kondisi lingkungan yang baik untuk bercocok tanam, berdasarkan kebutuhan mereka terhadap alam ini masyarakat menggap pembangunan Pembangkit Listrik Tenaga Panas Bumi (PLTP) ini akan menimbulkan kerusakan alam artinya mereka memiliki pandangan tidak baik rencana pembangunan ini. Sedangkan masyarakat yang minoritas membutuhkan pembangunan ini untuk menuju sebuah perubahan.

Keempat Sistem nilai yang berlaku dalam masyarakat Nagari Batu Bajanjang dalam pengambilan keputusan sejak nenek moyang mereka selalu dilakukannya musyawarah, akan tetapi saat pemberian izin eksploitasi wilayah mereka, mereka dikagetkan karena tidak ada pemberitahuan dan musyawarah terlebih dahulu. Dengan keadaan seperti ini mereka merasa sistem nilai mereka terpinggirkan sehingga keadaan ini membuat masyarakat berpandangan dan berpersepsi buruk terhadap rencana pembangunan Pembangkit Listrik Tenaga Panas Bumi (PLTP) karena merasa akan dikuasai dan dimarjinalkan oleh pihak yang mempunyai 
kepentingan. Kelima tipe kepribadian, berdasarkan kenyataan yang penulis temukan dilapangan persepsi masyarakat Nagari Batu Bajanjang sangat dipengaruhi oleh tipe kepribaidian masyarakat dimana penulis menemukan kenyataan mayoritas masyarakat Nagari Batu Bajanjang adalah masyarakat yang mempunyai rasa keingin tahuan yang tinggi meskipun banyak masyarakat yang hanya mengenyam pendidikan hanya sampai di bangku SMA dan SMP namun ada juga sebahagian kecil masyarakat suka dipengaruhi seperti bedasarkan data hasil wawancara menulis dengan masyarakat yang menyatakan bahwa mereka ikut demo karna ikut-ikutan dengan masyarakat yang lain. Sesuai dengan teori Kelley (dalam Listyana dan Yudi, 2015:123).

Berdasarkan temuan lapangan, persepsi masyarakat di Nagari Batu Bajanjang, terbagi dalam dua kelompok berdasarkan pendapat mereka mengenai rencana pembangunan PLTP Gunung Talang. Sebagian besar menyatakan tidak setuju dan sebagian kecil setuju. Di bawah ini merupakan uraian dari kedua kelompok tersebut:

\section{1) Setuju}

Persepsi masyarakat yang setuju terhadap rencana pembangunan ini tidak datang begitu saja. Sejalan dengan teori persepsi Liliweri (1997:138) dalam Djumanty (2015:25-26) yang menjelaskan persepsi sering kali dimaknai dengan pendapat, sikap, penilaian, perasaan dan lain-lain. Persepsi selalu menggambarkan pengalaman manusia tentang objek, peristiwa atau hubunganhubungan yang diperoleh dengan menyimpulkan informasi atau menafsirkan pesan tentang objek tersebut.
Berdasarkan hasil temuan lapangan dapat dikatakan bahwa, masyarakat mendapatkan informasi tentang PLTP melalui kegiatan sosialisasi yang dilakukan oleh pemerintahan Nagari Batu Bajanjang, pemerintahan daerah Kabupaten Solok serta pihak Perusahaan PT Hitay Daya Energy selain itu juga didatangkan ilmuan atau para ahli energi panas bumi. Informasi yang diberikan yaitu berkaitan dengan manfaat dan dampak-dampak positif dari Pembangkit Listrik Tenaga Panas Bumi. Sehingga masyarakat tidak keberatan terhadap rencana pembangunan pembangkit listrik tersebut. Selain informasi tersebut, yang membuat masyarakat setuju adalah masyarakat Nagari Batu Bajanjang mempunyai harapan-harapan yang besar dengan adanya pembangunan pembangkit listrik tenaga panas bumi ini. Harapan tersebut di antaranya yaitu masyarakat akan mendapatkan pekerjaan agar mereka akan menerima gaji bulanan, ramah lingkungan, memenuhi kebutuhan listrik di Kabupaten solok, infrakstruktur daerah khususnya nagari akan menjadi lebih baik. Dengan adanya hal tersebut masyarakat temotivasi untuk mewujudkan suatu perubahan yang besar, yang mereka anggap dapat mensejahtetakan hidupnya. Sesuai dengan penelitian yang dilakukan oleh Mary R.T. dkk (2017:223).

\section{2) Tidak Setuju}

Berdasarkan penelusuran yang dilakukan oleh penulis di Nagari Batu Bajanjang, mayoritas masyarakat yang berada di nagari tersebut menolak (tidak setuju) terhadap rencana pembangunan PLTP karena mereka takut terhadap dampak lingkungan seperti terjadinya bencana alam, polusi udara, kerusakan hutan dan termarjinalkannya masyarakat 
lokal. Ketakutan masyarakat Nagari Batu Bajanjang terhadap dampak lingkungan sejalan dengan rencana pembangunan PLTP Bedugul di Bali, yang mana mereka menolak terhadap rencana pembangunan ini, dalam tulisan Ardhana (2009:292). Berdasarkan penelitian yang dilakukan oleh PPLH Unud tentang Amdal. Ditemukan bahwa dengan adanya pembangunan PLTP Bedugul akan memunculkan dampak negatif yaitu masalah amblesan atau turunnya permukaan tanah pada saat volume cairan menurun dan tidak dapat diprediksi kapan akan terjadi, kerusakan hutan lindung yang menyebabkan hilangnya satwa dan akan menurunkan biodiversitas flora dan fauna, hilangnya sumber mata air dan hilangnya identitas budaya masyarakat setempat.

Berdasarkan kenyataan yang penulis temukan bahwa hubungan masyarakat dengan perusahaan tidak baik hal ini terlihat pada saat masyarakat melakukan protes pada saat pihak perusaahaan melakukan peninjauan lokasi pembangunan yang berujung anarkis dan masyarakat merasa terganggu dengan adanya pembangunan PLTP di nagari mereka.Hal ini sesuai dengan teori dampak sosial menurut fardani dalam Agustina I.F dan Ricka O. (2016). dampak sosial merupakan suatu bentuk akibat atau pengaruh yang terjadi karena adanya sesuatu hal. Pengaruh yang dimaknai adalah efek yang berlaku dalam masyarakat baik karena sesuatu kejadian itu mempengaruhi masyarakat atau hal lainnya didalam masyarakat.

Menurut walginto (dalam Kuntyassari dan Austin, 2014:53) ada tiga aspek yang mempengrauhi persepsi yaitu, pertama aspek kognisi yang berhubungan dengan pengenalan akan objek peristiwa. Kedua aspek afeksi yang berhubungan dengan emosi dan.Ketiga aspek konasi yang berhubungan dengan kemauan. Teori tersebut sesuai dengan kenyataan yang penulis temukan dilapangan yang mana masyarakat menolak (tidak setuju) dengan rencana pembangunan karena minimnya informasi dan pengetahuan yang masyarakat dapatkan, masyarakat Nagari Batu Bajanjang hampir sebagian besar tidak mengetahui betul mengenai pembangunan PLTP seperti bagaimana pengembangan pembangunan, bagaimana proses pembangunan, apa dampak dan manfaat yang ditimbulkan masyarakat tidak memahami itu sehingga mereka menafsirkan sendiri pembangunan PLTP tersebut. Ketidak pahaman masyarakat terhadap pembangunan PLTP membuat masyarakat tidak dapat berpartisipasai aktif dalam pembangunan dan menolak pembangunan yang akan dilakukan. Sesuai dengan teori Persepsi menurut Sarlito dalam Rohmatul listyana \& Yudi Hartono (2015).

Jadi berdasarkan hasil penelitian persepsi masyarakat di Nagari Batu Bajanjang terhadap rencana pembangunan pembangkit listrik tenaga panas bumi (PLTP) Gunung Talang, ditunjukkan dengan dukungan dengan menaruh harapan pembangunan ini akan membawa kepada perubahan menuju kesejahteraan dan yang menolak pembangunan ditunjukkan dengan protes menentang pembangunan. Sesuai dengan teori S.Sttanfeld (dalam Listyana dan Yudi, 2015:123) yang menjelaskan sikap merupakan kecendrungan berbuat atau bereaksi secara senang atau tidak senang terhadap orang-orang, objek atau situasi.
1. Upaya Pemerintah Nagari Batu Bajanjang Dalam Pemberian 


\section{Pemahaman kepada masyarakat Terhadap Rencana Pembangunan Pembangkit Listrik Tenaga Panas Bumi (PLTP) Gunung Talang}

Berdasarkan kenyataan yang penulis temukan dilapangan bahwa pemerintah Nagari Batu Bajanjang telah memberikan upaya sosialisasi kepada masyarakat dan tokoh-tokoh nagari terhadap rencana pembangunan pembangkit listrik tenaga panas bumi (PLTP) Gunung Talang bersama-sama dengan pemerintah daerah Kabupaten Solok dan pihak PT. Hitay. Menurut teori David A. Goslin dalam (Abdullah N dan Kharisma N, 2018:124), sosialisasi merupakan proses belajar yang dialami seseorang untuk memperoleh pengetahuan, keterampilan, nilai-nilai dan norma-norma agar ia dapat berpartisipasi sebagai anggota dalam kelompok masyarakat. Sosialisasi yang dilakukan tidak sekali saja namun dilaksankan lebih dari tujuh kali. Sosialisasi ini dilakukan untuk memperkenalkan PLTP kepada masyarakat tidak hanya itu sosialisasi ini dilakukan supaya masyarakat ikut serta berpartisipasi aktif dalam pembangunan ini. Sosialisasi yang dilakukan langsung kepada masyarakat digambarkan dalam table berikut:

Tabel 1

Sosialisasi Kepada Masyarakat

\begin{tabular}{|c|l|l|l|l|}
\hline $\begin{array}{l}\mathbf{N} \\
\mathbf{O}\end{array}$ & Pemateri & \multicolumn{1}{|c|}{ Materi } & Tempat & Partisipan \\
\hline 1 & Edisar & $\begin{array}{l}\text { pengenalan PT } \\
\text { Hitay Daya } \\
\text { Energi kepada } \\
\text { masyarakat }\end{array}$ & $\begin{array}{l}\text { Masjid } \\
\text { Raya } \\
\text { Batu } \\
\text { Bajanjan } \\
\mathrm{g}\end{array}$ & 700 orang \\
\hline 2 & $\begin{array}{l}\text { Nofianto } \\
\text { dan Edisar }\end{array}$ & $\begin{array}{l}\text { sosialisasi } \\
\text { pengenalan } \\
\text { PLTP kepada } \\
\text { masyarakat } \\
\text { guna } \\
\text { menyatukan } \\
\text { pendapat }\end{array}$ & $\begin{array}{l}\text { Masjid } \\
\text { Raya } \\
\text { Batu } \\
\text { Bajanjan } \\
\text { g }\end{array}$ & 680 orang \\
& & \\
\hline
\end{tabular}

\begin{tabular}{|l|l|l|l|l|}
\hline 3 & tenaga ahli & manfaat & masjid & 800 orang \\
& Panas & pembangunan & raya & \\
bumi & $\begin{array}{l}\text { PLTP bagi } \\
\text { masyarakat } \\
\text { sekitar } \\
\text { pembangunan }\end{array}$ & Bajanjan & \\
& & & & \\
\hline
\end{tabular}

(Sumber: Ulil Amri, 2020)

Sesuai dengan teori Adisasmita (dalam Prasojo R.A dan Luluk F, 2015:53) yang mengerucutkan peran pemerintah desa dalam pembangunan yaitu sebagai penyampai pesan pembangunan, pengarah masyarakat untuk berpartisipasi dan penyalur aspirasi masyarakat. Peranan tersebut sangat berpengaruh terutama dalam upaya untuk menciptakan partisipasi dan pemberdayaan masyarakat pedesaan.

Dari teori di atas, dapat disimpulkan bahwa peran pemimpin secara umum meliputi peran sebagai pelopor, inovator, fasilitator, stabilitator, sekaligus mediator bagi berbagai kepentingan warga yang dipimpinnya. Kaitan antara peran pemerintah dengan pembangunan harus saling berkesinambungan. Artinya, seorang pemimpin harus menjalankan berbagai peran tersebut sesuai konteksnya mulai dari perencanaan, pelaksanaan, hingga saat evaluasi pembangunan.

Namun dari pengamatan yang dilakukan peneliti, keikutsertaan masyarakat belum sepenuhnya diikuti, karena program-program yang digagas pemerintah nagari hanya diketahui oleh sebagian masyarakat. Sosialisasi yang dilakukan pemerintah pun tidak berjalan dengan efektif karena masyarakat menganggap dalam sosialisasi pemerintah tidak menjalankan perannya yaitu, pertama sebagai inovator yang menggugah keinginan dan keikutsertaan masyarakat dalam pembangunan serta seharusnya pemerintah selalu bekerja sama dalam menyiapkan program 
pembangunan minsalnya dalam perencanaan program sampai evaluasi program pembangunan PLTP hal inilah yang membuat kecewa masyarakat Nagari Batu Bajanjang karena tidak dibawa bekerja sama dalam pengambilan keputusan perizinan pembangunan PLTP dan masyarakat diberitahu secara mendadak ketika proses eksploitasi akan dijalankan.

$$
\text { Kedua pemerintah telah }
$$
menjalankan perannya sebagai motivator dengan cara pihak pemerintah Kabupaten Solok, Pemerintah Nagari Batu Bajanjang serta pihak PT Hitay melakukan sosialisasi dengan membawa pemateri yang ahli dalam pemanfaatan energy panas bumi dan menyampaikan kepada masyarakat manfaat serta dampak-dampak positif pembangunan PLTP bagi kesejahteraan hidup masyarakat Nagari Batu Bajanjang. Namun sayang usaha memotivasi masyarakat yang dilakukan ini tidak begitu berpengaruh bagi kebanyakan masyarakat dan mereka bersikukuh untuk melakukan penolakan terhadap rencana pembangunan PLTP Gunung Talang ini.

Ketiga fasilitator pemerintah nagari maupun pemerintah daerah telah memfasilitasi masyarakat untuk menyampaikan aspirasinya seperti memperbolehkan masyarakat demo asalkan tidak anarkis. Akan tetapi peran pemerintah sebagai fasilitator ini tidak optimal karena berdasarkan kenyataan yang penulis temukan dilapangan bahwa pemerintah nagari dalam hal menfasilitasi penampungan aspirasi masyarakat terhadap rencana pembangunan PLTP ini tidak ada. Sosialisasi yang dilakukan pemerintah tidak hanya dilakukan untuk memperkenalkan PLTP kepada masyarakat akan tatapi juga untuk media musyawarah. Dalam musyawarah tersebut, masyarakat mempunyai keleluasaan untuk menyampaikan pendapat. Sesuai dengan teori Huraerah (dalam Laksana, 2013: 61), bahwa dalam pembangunan masyarakat bisa berperan untuk menyumbangkan pemikiran dalam ajang pertemuan atau rapat.

Kenyataan yang terjadi di Nagari Batu Bajanjang, permasalahan sering kali muncul dalam tahap penentuan persamaan pendapat untuk satu kepentingan. Salah satunya adalah ketidak samaan pandangan tentang pesan pembangunan yang disampaikan oleh pihak pemerintah kabupaten, nagari dan pihak PT. Contohnya, di satu pihak memandang bahwa pembanguanan ini tidak bisa dilaksanakan karana akan membahayakan masyarakat atas dampak negatif yang akan ditimbulkan sementara pada pihak lain menganggap pembangunan ini akan membawa masyarakat kepada kesejahteraan karena akan menyokong perekonomian dan kebutuhan masyarakat dalam ketenagalistrikan. Akibatnya perdebatan terjadi, semua pihak merasa mempunyai hak yang sama untuk menyampaikan pendapat.

\section{Kesimpulan}

Berdasarkan temuan di lapangan dapat dijelaskan bahwa rencana pembangunan Pembangkit Listrik Tenaga Panas Bumi (PLTP) Gunung Talang yang akan dilakukan oleh PT Hitay Daya energi menimbulkan berbagai pandangan atau persepsi dari masyarakat Nagari Batu Bajajang, secara umum terdapat dua kelompok persepsi masyarakat yaitu menerima (setuju) dan 
menolak (tidak setuju). Kelompok masyarakat yang menerima (setuju) atas rencana pembangunan ini hanya sebahagian kecil saja yaitu berkisar $20 \%$ dari jumlah penduduk nagari batu bajanjang. alasan masyarakat setuju terhadap rencana pembangunan pembangkit Listrik Tenaga Panas Bumi (PLTP) Gunung Talang karena pembangunan ini diharapkan dapat membuka lapangan pekerjaan, meningkatkan pendapatan daerah, meningkatkan pembangunan infrastruktur, serta memenuhi kebutuhan listrik yang kian hari makin meningkat.

Disisi lain sebahagian besar masyarakat Nagari Batu Bajanjang menolak (tidak setuju) dengan rencana pembangunan PLTP Gunung Talang. Hal tersebut disebabkan oleh adanya unsur kekhawatiran masyarakat terhadap bencana alam yang ditimbulkan dan ketakutan masyarakat terhadap kerusakan alam yang terjadi seperti kekeringan yang dapat mengancam perekonomian masyarakat dimana 95\% masyarakat Nagari Batu Bajanjang menggantungkan hidup mereka pada pertanian.

Disamping itu untuk meningkatkan pemahaman masyarakat terhadap pembangunan PLTP pemerintah nagari melakukan sosialisasi kepada masyarakat bersama-sama dengan pemerintah daerah dan pihak PT Hitay Daya Energi. Akan tetapi sosialisasi tidak berjalan optimal, karena dalam proses sosialisasi masyarakat merasa kurang dilibatkan.

Keterlibatan masyarakat dalam sosialisasi sangat dibutuhkan untuk melihat bagaimana partisipasi masyarakat dalam pembangunan jadi dalam proses sosialisasi sangat memerlukan komunikasi yang baik agar sosialisai dapat berjalan optimal dan menghindari kesalah pahaman.

\section{Referensi}

Abdullah N.N dan Kharisma N. (2018). Pengaruh Sosialisasi Terhadap Pengetahuan Pelajar Mengenai Hoax. Channel, 6(1):106-119

Alpriandi. dkk. (2019). Dampak Pembangunan Waduk Kuwil Terhadap Sosial Ekonomi Masyarakat di Sekitar Pembangunan Waduk Kuwil Desa Kawang-Koan Kabupaten Minahasa Utara. AGRIRUD, 1(1): 20-30

Ardhana, IPG. (2009). Sinkronisasi Kegiatan Pertambangan Pada Kawasan Hutan. Jurnal Bumi Lestari, 9( 2): $288-299$

Agustina I.F dan Ricka O. (2016). Analisis Dampak Sosial dan Ekonomi Kebijakan Pengembangan Kawasan Mix Use di Kecamatan Jabon. JKMP, 4(2):117-234

Budianta, A. (2010). Pengembangan wilayah perbatasan sebagai upaya pemerataan pembangunan wilayah di Indonesia. Jurnal SMARTek, 8(1): 72-82

Djumaty, B. L. (2015). Dari “ya" menjadi "tidak" studi tentang persepsi dan sikap masyarakat Desa Idamdehe terhadap rencana pembangunan PLTP di Idamdehe dan Idamdehe Gamsungi.KRITIS, Jurnal Studi Pembangunan Interdisiplin, XXIV(1): 21-39

Hadi, E. S. dan Eka, V. P (2019). Resistensi masyarakat terhadap rencana pembangunan PLTP (Pembangkit Listrik Tenaga Panas Bumi) di Gunung Talang Kabupaten Solok. Jurnal Perspektif: Jurnal Kajian Sosiologi dan Pendidikan, 2(3): 236-244 
Kuntyassari, A. A. dan Agustin, H. (2014). Hubungan antara persepsi terhadap lingkungan kerja dengan kepuasan kerja pada karyawan radio jaringan cipta prima pariwara radionet Semarang. Proyeksi, 9(2): 49-60

Laksana, N. S. (2013). Bentuk-bentuk Partisipasi Masyarakat Desa dalam Program Desa Siaga di Desa Bandung Kecamatan playen Kabupaten Gunung Kidul Provinsi Daerah Istimewa Yogyakarta. Kebijakan dan manajemen public, 1(1):56-67

Listyana, R. dan Yudi, H. (2015). Persepsi dan sikap masyarakat terhadap penanggalan Jawa dalam penentuan waktu pernikahan (studi kasus Desa Jonggrang, Kecamatan Barat, Kabupaten Magetan tahun 2013). Jurnal Agastya, 5(1): 118-138

Mangensiga,F. dkk. (2020). Investigasi sebaran lumpur panas menggunakan metode geolistrik tahanan jenis konfigurasi DipolDipol di Desa Karumenga sebagai mitigasi bencana alam. JURNAL MIPA, 9(1): 14-17

Mary, R.T. dkk.(2017). Panas Bumi Sebagai Harta Karun Untuk
Menuju Ketahanan Energi.Jurnal Ketahanan Nasional, 23(2): 217-237

Meilani, H. dan Dewi, W. (2010). Potensi panas bumi sebagai energi alternatif pengganti bahan bakar fosil untuk pembangkit tenaga listrik di Indonesia. Jurnal Ekonomi $\mathcal{E}$ Kebijakan Publik, 1(1): 47-74

Moleong, Lexy J. (2013). Metodologi Penelitian Kualitatif. Bandung: PT Remaja Rosdakarya

Prasojo R.A dan Luluk F. (2015). Peran Pemerintah-Masyarakat dalam Pembangunan Desa Sedatigede Kecamatan Sedati Kabupaten Sidoarjo. JKMP, 3(1): 49-64

Sugiyono. (2017). Metode Penelitian Kuantitatif Kualitatif dan RED. Bandung: Alfabeta

Supyana, R. H. (2016). Persepsi masyarakat terhadap pembangunan PLTU di Desa Ujung Negoro, Kecamatan Kandeman, Kabupaten Batang (kajian tingkat pendidikan).Jurnal Geografi, 13(2): 151-224

Utari, L. R. dkk. (2019). Pengembangan petunjuk praktikum pada mata kuliah perlakuan panas di program studi pendidikan teknik mesin Universitas Sriwijaya. Jurnal Pendidikan Teknik Mesin, 6(1): 68-77 